\title{
The Language in My Tongue
}

\author{
Susan Hawthorne
}

\section{La langue dans ma langue}

Poèmes de la parole épileptique, ces textes visent à nous faire saisir combien parler est une performance. Quand on est une fenme, les mots nous tombent de la bouche, ils nous mettent souvent en colère, en transes et nous les vomissons. Le rapport entre le langage qui nous annule et l'être-femme que nous tentons de devenir serait-il une maladie dont nous souffrons toutes? 
GRAND MAL

I am an electrical impulse.

I dance.

I jump.

I leap across the abyss of the synapse.

I am an excessive and disorderly discharge.

I defy definition.

I recur from time to time.

I am random.

I am entirely cerebral.

I am at the threshold of a seizure.

Grand mal.

Idiopathic.

I give no warning.

I have no aura.

I leap from synapse to synapse.

I create disorder.

She cries out.

I dance.

She waves her arms about.

Everything is in a state of flux.

She falls.

Her pupils dilate.

Her teeth bite into the tongue.

I am dancing.

Her face is blue.

Like the blue of cyanide.

I rampage.

I rage.

Her muscles contract.

She is seized.

She is prone.

She convulses.

Saliva dribbles from her mouth.

Saliva mixed with blood.

Her arms are bruised.

She is comatose.

She is unrousable.

She has lost consciousness. 
TRANSFORMATION

She said to you:

I turned round to see what you

were staring at.

There was nothing.

That's when you fell.

When I wasn't watching.

When I turned back

your body was quivering,

shivering, shaking.

I don't know how long it lasted.

Two minutes or ten.

It felt like an hour.

I let you be. When you stopped shaking, I held you.

It was a while before you woke.

Your eyes empty, not sparkling

as they usually do. They closed again and inside some transformation took place. When they opened again

they were alive. Then you slept, breathing like a baby. 
FIRST BREATH

The first breath I took

was late.

I've been holding it ever since.

An amniotic sea pushing

me forwards.

But something was holding me back.

The doctor was late, so

I was late too.

He breathed his lunch on me. 
MINIATURE DEATH

I dream of drowning

swimming upwards from the seabed

of unconsciousness.

My mouth opens

gasping for breath

like a fish near death.

I drown in my own held breath,

no water, no sea

just a miniature death. 


\section{FALLING WOMAN}

I am the subject of my subject.

I fall.

I, the subject,

am subject to falling.

I fall in any old way.

I fall

sitting on a mattress

(the best way to fall)

I fall

sitting on a bicycle

sitting on a chair

sitting between people

I fall

standing in the shower

making a phone call

I fall

already lying down

sleeping in my bed

I fall in any old place

I fall

in bed with my lover

in the milk bar with unknown people

at home over breakfast

at work over my desk

I fall

in a meeting

in a hotel room

in a strange city

I am a woman who is subject to falling 
NO NAMES

There are days when time falls away from me.

I cannot answer questions you put to me.

I have no words to answer with.

I see things.

I know there are names attached to the things.

I know I know them.

But the names are not there.

I have no name.

You have no name.

You are simply there. 
TONGUE WITHOUT WORDS

I have no words to answer with

words

fall

into the void

echoes

empty;

of meaning

simple

sounds

stroking my waxy ears

I have no words to answer with

the tongue

furled

and hollow

the tongue

grasping

to feel meaning

the tongue

flat

out to speak

I have no words to answer with

the grey matter

without

static

no

electrical charge

to spark meaning

no

thing to

matter

no thing matters

nothing matters

I mutter

something 
something

explodes

in my brain

in my grey matter

something matters

my tongue

stretches

for the word

my tongue

lifts

presses against teeth

my tongue

curls around a word

a hollow of meaning

a sound

escapes

the hollow curve of my mouth

a word

I have a word

I have found the words

the words fall

in a rush

spitting

frothing

words rush out

filling the void 